Mary Francis

\title{
The issues facing librarians and physicians Facilitating quality research in the Internet age
}

$\mathbf{R}_{t}^{\mathrm{e}}$ ecently while listening to Talk of the Nation on National Public Radio, ${ }^{1}$ I heard a doctor comment on how his patients were turning to the Internet to conduct research on their health. My thought, Welcome to my world. As a reference and instruction librarian, I have continually been faced with students who use the Internet as the end all and be all of their research. I spend time during each instructional session I teach to note how the Internet will not provide the same quality material as that found within the academic journals indexed in the library s databases. Physicians face a similar problem when patients nd poor-quality health information online. The American Medical Association in 2000 went so far as to send out a press release asking patients to make a New Year s resolution not to go online. ${ }^{2}$ This call, like the desire of many librarians for an Internet ban on research, went unheeded.

It is not surprising that both students and patients are turning to the Internet for their needs. Try as we may to offer quality services to our patrons, it remains practically impossible to offer the $24 / 7$ service available from the Internet. To those librarians who still hold out against the evil of Google, I send out a call to accept the inevitability of the Internet as many physicians have done. In a shift from the 2000 call, a 2005 study by the National Cancer Institute noted that most physicians want to hear about the research their patients have done online. ${ }^{3}$ This is not to say that we must give up our patrons to the Internet, but rather, we must accept their use of online sources and incorporate it into our interactions with them.

In the interview, Ted Eytan notes that a good doctor will embrace the information brought in by the patient as a starting point. ${ }^{4}$ Likewise, librarians cannot simply scorn the student who comes to them with a Wikipedia article. Rather, we must take the information from that article and use it with the student in a productive way. We must give credit to the student for starting the search within their own knowledgebase, but then it is up to us to help extend that knowledge of where to search. Does the bibliography give us new places to nd information? Does the content provide unique keywords to be applied in our searches?

Physicians will encounter patients coming to them declaring they need a prescription for drug X or claiming they have disease Y. Librarians also face this situation when a student asks for a speci $\mathrm{c}$ journal or book on a particular topic. At this point, both librarians and physicians must step back from giving out the journal or prescription and conduct a reference interview in order to ask why. Both groups must have a complete picture of the problem before they can offer advice. Will it really help the student to know that the back issues of Southern Literary Journal are bound in the stacks, when their paper is concerned with how slave narratives gave a voice to early African Americans? Librarians cannot simply give out location information and hope the students nd what they need,

Mary Francis is reference/instruction librarian at Dakota State University, e-mail: mary.francis@dsu.edu

(c) 2008 Mary Francis 
just as physicians cannot give out a prescription and hope it makes the patient better. Both groups must apply their expertise to the given situation in order to determine what will be the best material/diagnosis.

The Internet with its good sites and bad sites, has forced librarians and physicians to go beyond their comfort zones and to innovate. The breath and reach of our services can now extend far beyond the library or hospital. We are no longer the simple providers of information, but we are needed to help interpret that information. Evaluation and critical thinking skills have become vital components in choosing information. This is seen throughout the library and referenced by Susannah Fox, associate director at the Pew Internet and American Life Project, who notes that three fourths of individuals do not check the source or date when looking at health information online. ${ }^{5}$

To combat this, one caller on the Talk of the Nation show made the suggestion that doctors provide their patients with a list of Web sites they would recommend as containing quality material. Fortunately, this list has already been compiled by the Medical Library Association. ${ }^{6}$ With the Internet continuing to impact the daily workings of librarians and physicians, it is up to both groups to rise to the challenge and show that they truly are professionals.

\section{Notes}

1. Neal Conan, Do-It-Yourself Diagnosis on the Web, Talk of the Nation, December 13, 2007, www.npr.org/templates/story/story. php?storyId=17214066.

2. Joseph Shapiro, Patients Turn to the Internet for Health Information, Morning Edition, October 11 2007, www.npr.org /templates/story/storyphp?storyId=15166387>.

3. Ibid.

4. Conan, Talk of the Nation.

5. Ibid.

6. MLA User s Guide to Health Information, see Www.mlanet.org/resources /userguide.html. $\boldsymbol{n}$

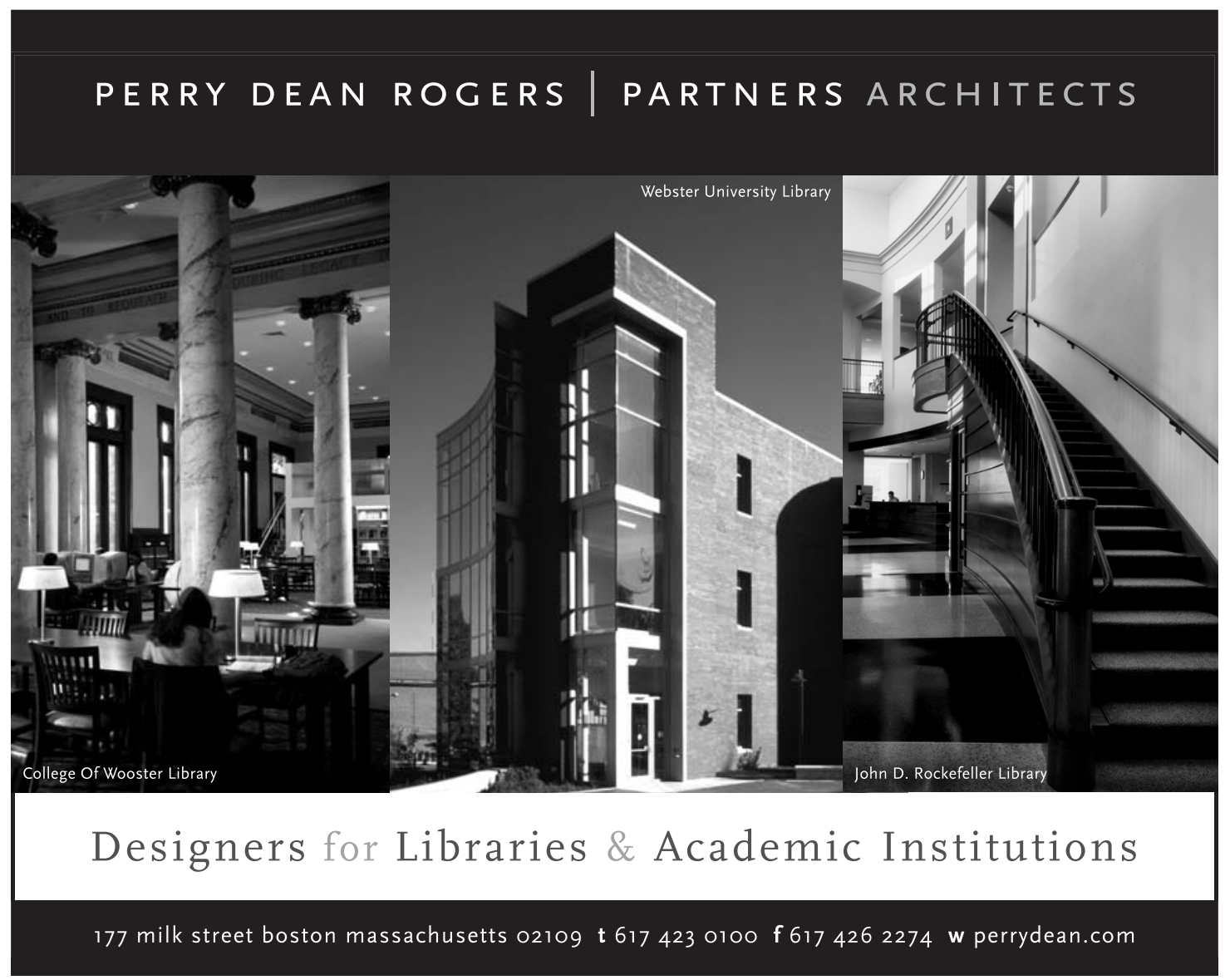

